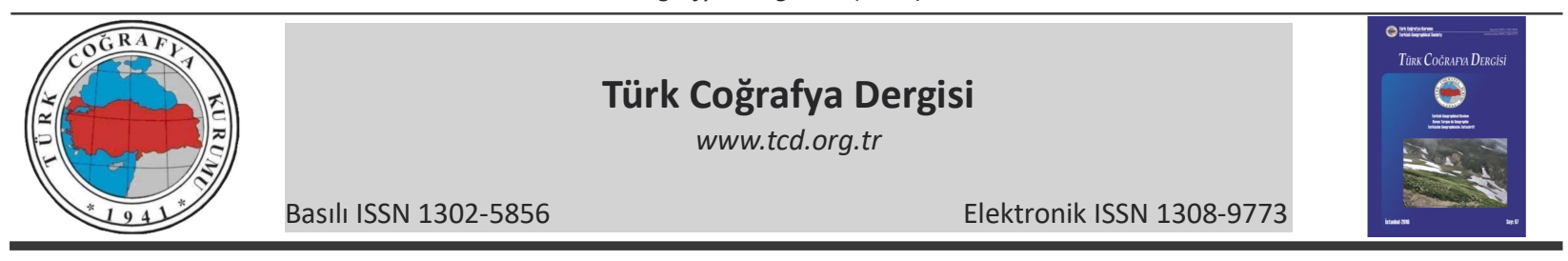

\title{
Türkiye şekerpancarı üretiminde Yozgat ilinin yeri ve önemi
}

\section{The place and significance of the province of Yozgat in sugar beet production in Turkey}

\author{
Hakan Koça* ihsan Bulut ${ }^{b}$ \\ ${ }^{a}$ Cumhuriyet Üniversitesi, Eğitim Fakültesi, Sosyal Bilimler ve Türkçe Eğitimi Bölümü, Sivas. \\ ${ }^{b}$ Akdeniz Üniversitesi, Edebiyat Fakültesi, Coğrafya Bölümü, Antalya.
}

\section{MAKALE BILGI}

Geliş/Received: 06.06.2016 Kabul/Accepted: 23.11.2016

Anahtar Kelimeler:

Şekerpancarı

Yozgat ili

Doğal faktörler

Beşeri faktörler

Keywords:

Sugar beet

Yozgat province

Natural factors

Human factors

*Sorumlu yazar/Corresponding author (H. Koç) hakankoc66@gmail.com

http://dx.doi.org/10.17211/tcd.281944

\section{ÖZ / ABSTRACT}

İnsanoğlu, günlük, sosyal ve ekonomik yaşamını sağlıklı yürütebilmesi için un, yağ, protein, tuz ve şeker vb. içerikli besin maddelerini düzenli ve sağlıklı bir şekilde tüketmek zorundadır. Insanların beslenme alışkanlıklarında tatıya ayrı bir yer ayırmaları nedeniyle şeker, hem tarih boyunca insanoğlunun önemli bir besin maddesi olmuş hem de farklı disiplinlerin araştrrma konusu olmuştur. Bu araştırma da şeker üretiminin önemli kaynaklarından birisi olan şekerpancarı üzerine odaklanmıștır. Araştırmanın amacı; Türkiye şekerpancarı üretiminde Yozgat ilinin yeri ve önemini tespit etmektir. Bu amaç doğrultusunda; aşağıdaki alt problemler belirlenmiş ve bu alt problemlere yönelik cevaplar aranmıștr. A. Türkiye şekerpancarı üretimi ne kadardır? Bu üretim illere göre nasıl bir dağıım göstermektedir? B. TÜiK (2015) verilerine göre, Yozgat ilinin şekerpancarı üretimi ne kadardır? Yozgat ili, Türkiye şekerpancarı üretiminin yüzde kaçını karşılamaktadır? C. Yozgat ilinde şekerpancarı üretiminin ilçelere göre dağılımı nasıldır? Bu dağıımda etkili olan coğrafi esaslar nelerdir? Araştırma tarama yöntemi ile yürütülmüştür. İstatiksel yöntem olarak ilişkisel analiz (Korelasyon) yöntemi kullanılmıştır. 2015 Türkiye İstatistik Kurumunun verilerine göre, 16.462.000 ülke genelinde şekerpancarı üretilmiştir. Şekerpancarı üretiminde Yozgat ili önemli bir potansiyele sahiptir. Konya ilinden sonra en fazla üretim Yozgat iline aittir. Yozgat ili 1.640 .493 ton şekerpancarı üretimi ile Türkiye şekerpancarı üretiminin \% 9.97'lik kısmını karşılamaktadır. Yozgat ilinde ilçelere göre şekerpancarı üretimine bakıldığında en fazla üretim Boğazııyan, Sarıkaya, Merkez ilçe, Sorgun ve Yerköy ilçelerinde yoğunlaşmaktadır. En az üretim Çayıralan, Çekerek, Saraykent ve Aydıncık ilçelerine aittir. Klimatolojik, jeomorfolojik, edafik ve hidrolojik faktörler şekerpancarı üretimine etki eden doğal faktörlerdir. Bu faktörlerden daha çok jeololojik ve topografik faktörler, Yozgat ilindeki pancar ekim alanlarını ve üretimini şekillendirmiştir. Illçelerin toplam tarım alanları ile şekerpancarı üretimi, toplam tarım alanı ile şekerpancarı ekim alanı, şekerpancarı ekim alanı ile şekerpancarı üretimi arasında yüksek düzeyde ve şekerpancarı ekim alanı ile şekerpancarı verimi arasında pozitif orta düzeyde bir ilişkinin (korelasyon) olduğu tespit edilmiştir.

Human beings have to consume such nutrients as flour, fat, protein, salt and sugar regularly and healthily to continue their daily, social and economic lives. As sweet food has a significant place in their nutritional habits, sugar has been not only a significant nutrient, but also a matter of investigation for various disciplines. This study focuses on sugar beet, one of the major sources for sugar production. The purpose of this study is to investigate the place and significance of Yozgat, a province in middle Anatolia, in sugar beet production. In line with this purpose, the answers to the following research questions were sought: A. How much sugar beet is produced in Turkey? What is the distribution of production across provincial areas in Turkey? B. How much is the sugar beet production in Yozgat, based on data from Turkish Statistical Institute (TSI)? What percentage of production in Turkey belongs to Yozgat? C. What is the distribution of production across counties in Yozgat? What are the geographical factors that affect such a distribution? This study is mainly based on literature review and correlational analyses. According to the data from Turkish Statistical Institute, 16.462.000 tons of sugar beet was produced in Turkey in 2015. Yozgat has a significant potential for sugar beet production. The second largest amount of production after Konya, another Middle Anatolian province, belongs to it. Yozgat boasts $9.97 \%$ of all sugar beet production in Turkey, with 1.640.493 tons. When the distribution of sugar beet production across counties of Yozgat is examined, Boğazlıyan, Sarıkaya, Yozgat's city center, Sorgun and Yerköy rank among the largest producers. The smallest amount of production belongs to the counties of Çayıralan, Çekerek, Saraykent and Aydıncık. Climatological, geomorphological, edaphic and hydrological come foremost among the natural factors that impact sugar beet production. Among these factors, it is the topographical structure that shapes the areas where sugar beet could be grown and the amount of production in these areas. A strong significant correlation was found between sugar beet production and the size of the total agricultural areas in the counties; the size of the area reserved for sugar beet production and the total agricultural area; the size of the sugar beet production area and sugar beet production, and finally size of the area for sugar beet production and sugar beet yield. 


\section{Giriş}

İnsanoğlu, günlük, sosyal ve ekonomik yaşamını sağlıklı yürütebilmesi için un, yağ, protein, tuz ve şeker vb. içerikli besin maddelerini düzenli ve sağlıklı bir şekilde tüketmek zorundadır. Insanların beslenme alışkanlıklarında tatlıya ayrı bir yer ayırmaları nedeniyle şeker, hem tarih boyunca insanoğlunun önemli bir besin maddesi olmuş hem de farklı disiplinlerin araştrrma konusu olmuştur. Bu araştırma da şeker üretiminin önemli kaynaklarından birisi olan şekerpancarı üzerine odaklanmıştir.

Dünyada sakkaroz ve nişasta kökenli olmak üzere iki tür şeker üretimi bulunmaktadır. Sakkaroz kökenli olarak şeker üretimi dünyada şeker pancarı ve şeker kamışından; nişasta kökenli olarak ise mısır şurubundan üretilmektedir" (Karaibiş ve Emeklier, 2012).

Şekerin hammaddesi olarak yetiştirilen şeker pancarı (Beta vulgaris var. saccharifera L.) Chenopodiaceae (Kazayagıgiller) familyasında yer alan bir endüstri bitkisidir. Şeker üretiminin yanı sıra melas, küspe, yaprak ve baş artıkları gibi yan ürünlerinden hayvan yemi, melastan alkol ve ispirto elde edilmesi, modern tarım tekniklerine uygun olması ve istihdam yaratması gibi nedenlerle önemli bir bitkidir (Şiray, 1990; akt; Yardımcı vd., 2012).

Türkiye'de şeker pancarı tarımının dağılışını etkileyen faktörler topografik özellikler, klimatolojik ve edafik faktörler ve şekerpancarına göre daha fazla kar getiren alternatif tarım ürünleridir. Türkiye'nin büyük bir kesiminde yaşanan klimatolojik koşullar, edafik faktörler, vejatasyon süresi gibi çeşitli doğal koşullar şekerpancarı tarımına büyük bir potansiyel sunmaktadır. Bu zengin potansiyel yurdumuzun farklı bölge ve yörelerinde birçok araştırmacı tarafindan ele alınıp değerlendirilmiştir (Kadıoğlu 2009, Çelikel 1989, Çatal ve Akınerdem 2013, Söğüt ve Arıoğlu 1999, Okut ve Yıldırım 2004, Yardımcı vd.,2012, Kaya vd., 2012).

Bu araştırma ile de Yozgat ilinin şekerpancarı üretim potansiyelini tespit edilmeye çalışılmıştır. Araştırma sahası Yozgat il sınırlarını kapsamaktadır. (Şekil 1).Yozgat i̇li, iç Anadolu Bölgesi'nin Orta Kızılırmak Bölümü'nde yer alır. Yozgat ili, doğudan Sivas, güneyden Kayseri ve Nevşehir, batıdan Kırşehir ve Kırıkkale, kuzeyden Amasya ve Çorum kuzeydoğudan da Tokat ili çevrilidir. Yozgat ili matematiksel konum olarak $34^{\circ} 05^{\prime}-36^{\circ}$ $10^{\prime}$ doğu meridyenleri ile $38^{\circ} 40^{\prime}-40^{\circ} 18^{\prime}$ kuzey paralelleri arasında bulunmaktadır. Yozgat ili, Harita Genel Komutanlığından alınan verilere göre 13.690 km² yüzölçümüne sahiptir. Yozgat ili yüzölçüm bakımından 15. sırada yer almaktadır.

Araştırmanın amacl; Türkiye şekerpancarı üretiminde Yozgat ilinin yeri ve önemini tespit etmektir. Bu amaç doğrultusunda; aşağıdaki alt problemler belirlenmiş ve bu alt problemlere yönelik cevaplar aranmıştır.

A. Türkiye şekerpancarı üretimi ne kadardır? Bu üretim illere göre nasıl bir dağılım göstermektedir?

B. TUiK (2015) verilerine göre, Yozgat ilinin şekerpancarı üretimi ne kadardır? Yozgat ili, Türkiye şekerpancarı üretiminin yüzde kaçını karşılamaktadır?

C. Yozgat ilinde şekerpancarı üretiminin ilçelere göre dağılımı nasıldır? Bu dağılımda etkili olan coğrafi esaslar nelerdir?
D. İl bazında toplam tarım alanı, şeker pancarı ekim alanı, şekerpancarı üretimi, verim ve şeker fabrikası arasında nasıl bir ilişki vardır?

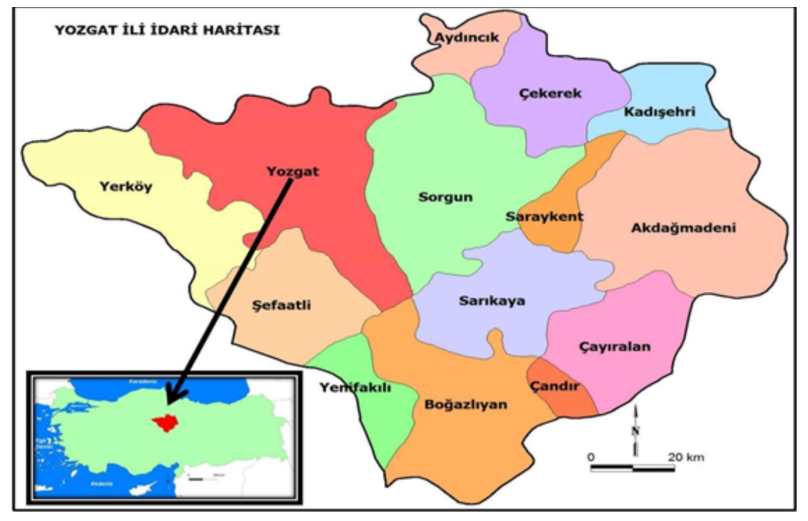

Şekil 1. Araştırma alanının lokasyon haritası.

Figure 1. Location map of study area.

\section{Yöntem}

Araştırmada ilişkisel tarama yöntemi kullanılmıştır. "Tarama yöntemi, geçmişte yâda halen var olan bir durumu var olduğu şekliyle betimlemeyi amaçlayan araştırma türüdür. Araşttrmaya konu olan olay, birey yâda nesne, kendi koşuları içinde ve var olduğu gibi tanımlamaya çalışılır"(Karasar,2005:77). Araştırmada verilerin analizinde betimsel istatistik ve Sperman's rho korelayon katsayı tekniğinden yararlanılmıştır.

\section{Bulgular}

3.1. Türkiye Şeker Pancarı Üretimi Ne Kadardır? Bu Dağılım İlere Göre Nasıl Bir Dağılım Göstermektedir?

Türkiye İstatistik Kurumunun verilerine göre, 2015 yılında ülkemizin şekerpancarı üretimi 16. 462.000 milyon tondur. İl bazında üretim değerleri incelendiğinde en fazla üretim 5.217.392 ton ile Konya iline aittir. Konya ilini, 1.640 .493 ton ile Yozgat ili takip etmektedir. Bu iki ili sırasıyla Aksaray (995.805), Kayseri (839.914) ve Eskişehir (841.231) illeri takip etmektedir. Şekerpancarı üretimi yapılan iller arasında, en az üretim ise 37 ton ile Kocaeli iline aittir.

Şekil 2 dikkatlice incelendiğinde; şekerpancarı üretiminin Orta Anadolu'da yoğunlaştı̆ı dikkat çekmektedir. Ülkemizde klimatolojik, ekolojik ve ekonomik olarak en uygun şekerpancarı yetiştirme alanları Orta Anadolu, İç Batı Anadolu'dur. Bu iki bölgenin yanı sıra geçiş bölgelerinde (Tokat, Çorum, Kastamonu ve Amasya) şekerpancarı üretimi oldukça iyi durumdadır. Şekerpancarı ülkemizde sulamalı yöntemle hemen her yerde yetiştirilebilmesine rağmen Doğu Karadeniz Kıyı kesiminde, Batı Karadeniz Kıyı kesiminde ve Güneydoğu Anadolu'da (Gaziantep ve Şanlıurfa hariç) yetiştirilmediği şekil 2'den net olarak anlaşılmaktadır.

Gündüz sıcaklıkları şeker pancarında en yüksek şeker yoğunluğ $20-23^{\circ} \mathrm{C}^{\prime}$ lerde meydana gelir. Ancak $26^{\circ} \mathrm{C}^{\prime}$ yi aşarsa şeker yoğunluğu önemli ölçüde düşer"(Avcı,1993). Güneydoğu Anadolu, Akdeniz ve Ege kıyı kesimlerinde şekerpancarı bitkisinin yetiştirilmemesindeki en önemli etken, şekerpancarı tarımında sıcaklılar $26^{\circ} C^{\prime}$ nin üzerine çıktı̆ı vakit, pancar bitkisindeki ge- 
lişim devam etmekte ve depo ettiği şekeri harcamaktadır. Bu durum verim düşüklüğüne neden olmaktadır. (Şekil 2). "Ege ve Akdeniz bölgelerimizin kıyı kesimlerinde yaz aylarında sıcaklığın $26^{\circ} \mathrm{C}^{\prime}$ nin üzerine çıkması şeker pancarının bu kesimlere girmesini engellemiştir. Bu alanlarda daha çok sıcaklıktan hoşlanan ürünler (pamuk, yerfistı̆̆ı, susam ve naranciye vb.) yer almıştrr"(Özçağlar, 1992).Türkiye şeker fabrikaları A.Ş’nin, şekerpancarı bitkisinin üretim planlamasına yönelik çalışmaları bu tarım ürününün coğrafi dağılımını etkileyen bir diğer önemli faktördür.

II bazında şekerpancarı üretimine etki eden toplam tarım alanı, şekerpancarı ekim alanı, üretim, verim ve şekerpancarı fabrikası arasındaki ilişkiyi değerlendirmek amacıyla Sperman's Rho korelasyon analizi yapılmıştr.(Tablo 1). Bu analiz yöntemi verilerin normal dağılım göstermediği durumlarda kullanılmaktadır.

Korelasyon katsayısı 0.70 ile 1.00 arasında ise ilişkinin yüksek düzeyde, 0.70 ile 0.30 arasında olması ilişkinin orta düzeyde 0.30 ile 0.00 arasında olması ise ilişkinin düşük düzeyde olduğunu göstermektedir (Büyüköztürk, 2012).

il bazında toplam tarım alanı ile şekerpancarı ekim alanı arasında pozitif yönde, orta düzeyde ve anlamlı bir ilişki bulunmuş$\operatorname{tur}(r=0.50 ; p<0.01)$. Determinasyon katsayısı $\left(r^{2}=0.25\right)$ incelendiğinde; tarım alanındaki değişmelerin \% 25'inin ekim alanından kaynaklandığı, aynı şekilde ekim alanındaki toplam değişmelerin \% 25'inin tarım alanından kaynaklandığı söylenebilir. Başka bir anlatımla tarım alanı arttıkça ekim alanı da anlamlı bir farklılık oluşturacak şekilde artmaktadır.

II bazında toplam tarım alanı ile şekerpancarı üretimi arasında pozitif yönde, orta düzeyde ve anlamlı bir ilişki bulunmuştur $(r=0.50 ; \quad p<0.01)$. Determinasyon katsayısı $\left(r^{2}=0.25\right)$ incelendiğinde; tarım alanındaki değişmelerin \% $25^{\prime}$ inin üretimden kaynaklandığı, aynı şekilde üretimdeki toplam değişmelerin \% 25'inin tarım alanından kaynaklandığı söylenebilir.

Il bazında toplam tarım alanı ile verim arasında pozitif yönde, orta düzeyde ve anlamlı bir ilişki bulunmuştur $(r=0.45 ; p<0.01)$. Determinasyon katsayısı $\left(r^{2}=0.20\right)$ incelendiğinde; tarım alanındaki değişmelerin \% 20'sinin verimden kaynaklandığı, aynı şekilde verimdeki toplam değişmelerin \% 20'sinin tarım alanından kaynaklandığı söylenebilir.

II bazında şekerpancarı ekim alanı ile üretim arasında pozitif yönde, yüksek düzeyde ve anlamlı bir ilişki bulunmuştur $(r=0.99 ; p<0.01)$. Determinasyon katsayısı $\left(r^{2}=0.98\right)$ incelendiğinde; ekim alanındaki değişmelerin \%98'sinin üretimden kaynaklandığı, aynı şekilde üretimdeki toplam değişmelerin \% 98'sinin ekim alanından kaynaklandığı söylenebilir.

II bazında şekerpancarı ekim alanı ile şeker fabrikası sayısı arasında pozitif yönde, orta düzeyde ve anlamlı bir ilişki bulunmuştur $(r=0.55 ; p<0.01)$. Determinasyon katsayısı $\left(r^{2}=0.30\right)$ incelendiğinde; şekerpancarı ekim alanındaki değişmelerin \% 30'unun şeker fabrikası sayısından kaynaklandığı, aynı şekilde şeker fabrikası sayısındaki toplam değişmelerin \% 30'unun şekerpancarı ekim alanından kaynaklandığı söylenebilir.

İ bazında şekerpancarı üretimi ile şeker fabrikası arasında pozitif yönde, orta düzeyde ve anlamlı bir ilişki bulunmuştur $(r=0.52 ; p<0.01)$. Determinasyon katsayısı $\left(r^{2}=0.27\right)$ incelendiğinde; şekerpancarı üretimindeki değişmelerin \%27'sinin şeker fabrikasından kaynaklandığı, aynı şekilde şeker fabrika sayısındaki toplam değişmelerin \% 27'sinin şekerpancarı üretiminden kaynaklandığı söylenebilir.

Tablo 1. il bazında toplam tarım alanı, ekim alanı, üretim, verim ve şeker fabrikası arasındaki ilişkiyi gösteren Spearman korelasyon katsayısı sonuçları. Table 1. Spearman correlation coefficients showing the relationship between total agricultural area, area suitable for cultivation, production, fertility and the number of sugar factories across provices.

\begin{tabular}{lllllll}
\hline & & Tarım Alanı & Ekilen Alan & \multicolumn{1}{c}{ Üretim } & Verim & Şeker Fabrikası \\
\hline Tarım Alanı & Spearman's rho & 1 & $0.504^{* *}$ & $0.507^{* *}$ & $0.450^{* *}$ & $0.332^{*}$ \\
Ekilen Alan & Spearman's rho & $0.504^{* *}$ & 1 & $0.993^{* *}$ & $0.401^{* *}$ & $0.558^{* *}$ \\
Üretim & Spearman's rho & $0.507^{* *}$ & $0.993^{* *}$ & 1 & $0.481^{* *}$ & $0.527^{* *}$ \\
Verim & Spearman's rho & $0.450^{* *}$ & $0.401^{* *}$ & $0.481^{* *}$ & 1 & 0.077 \\
Şeker Fabrikası & Spearman's rho & $0.332^{*}$ & $0.558^{* *}$ & $0.527^{* *}$ & 0.077 & 1 \\
\hline
\end{tabular}

** Korelasyon 0.01 düzeyinde anlamlıdır.

* Korelasyon 0.05 düzeyinde anlamlıdır.

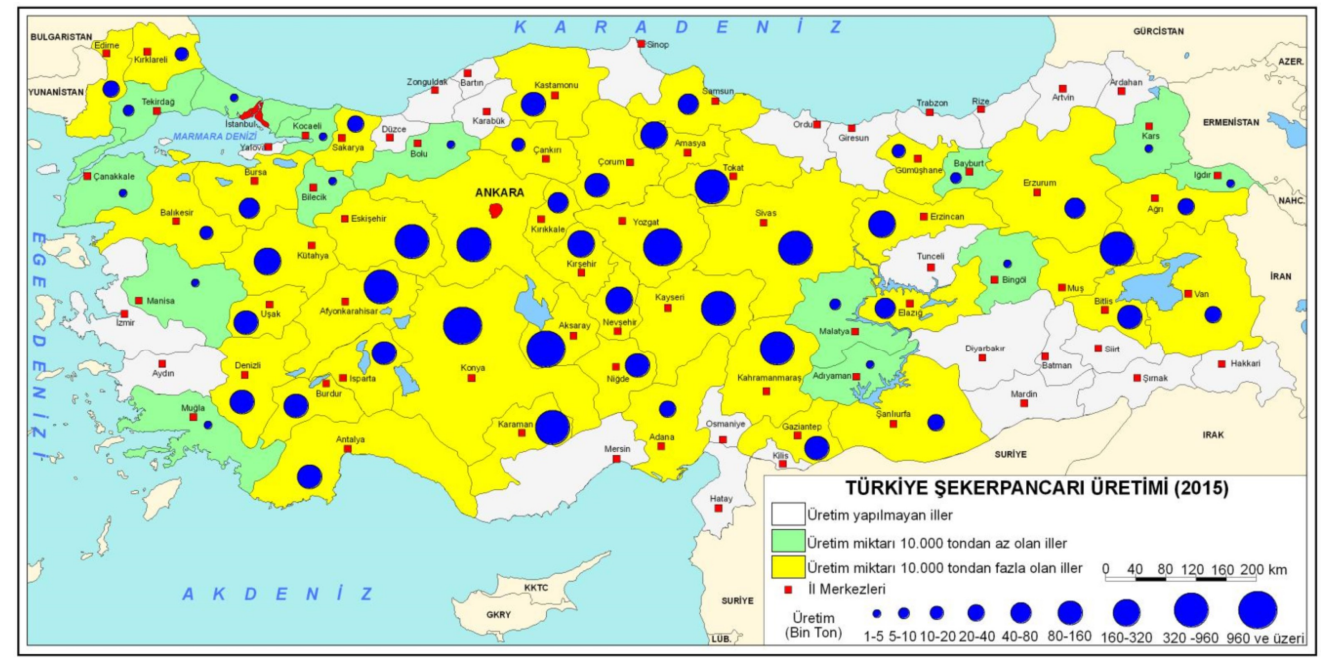

Şekil 2. Türkiye şekerpancarı üretimi (2015 /TÜiK).

Figure 2. Sugar beet production of Turkey (2015 /TÜiK). 
2015 yılında ülkemizde 25 tane kamu, 8 tanesi özel olmak üzere toplam 33 adet şekerpancarından üretim yapan şeker fabrikası bulunmaktadır (Şekil 3). Ülkemizde Mısırdan (Glikoz ve Fruktoz şurubu) nişasta bazlı şeker üretimi de yapılmaktadır. (Şekil 3).

“Türkiye'de şeker, 1990'lı yılların ikinci yarısına kadar sadece "şeker pancarı"ndan üretilmekte iken mısırdan "Nişasta Bazlı Şeker" (NBŞ) üreten şirketlerin faaliyete geçmesiyle, şekerpancarı ve mısırdan üretilmeye başlanmıştır. Yurtiçi seker tüketiminin ise \% 90'ı şekerpancarından, \% 10'u ise mısırdan karşılanmaktadır" (Konyalı ve Şatana,2012).

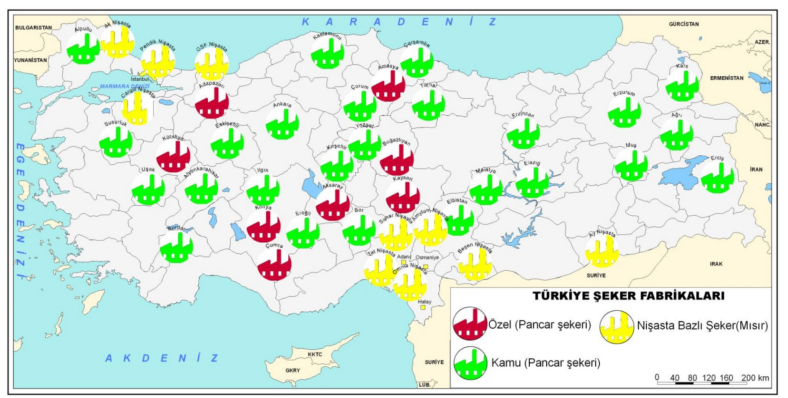

Şekil 3. Türkiye şeker fabrikaları (pancar / nişasta bazlı şeker) dağılış haritası. Figure 3. Distribution of sugar factories in Turkey.

Tablo 1'den anlaşılacağı üzere şeker fabrikası ile şekerpancarı üretim pozitif yönde orta düzeyde ilişki bulunmuştur. Ancak günümüz koşullarında bölge bazlı üretim ve fabrika sayıları analiz edildiğinde şeker fabrikalarının rantabıl dağılmadığı dikkat çekmektedir. (Tablo 2).

Doğu Anadolu'da bölge hayvancılığını daha da geliştirmek amacıyla, bu bölgeye fazla miktarda şeker fabrikası inşa edilmiş olabilir. Marmara Bölgesi 1999 yılından itibaren şekerpancarı bitkisinde uygulanan kota uygulamalarından dolayı, bu bölgede üretim değerleri azalma eğilimi göstermiştir.

Tablo 2. Bölgelere göre şekerpancarı ekim alanı, üretim ve fabrika sayıları (2015 TUiK)

Table 2. Sugar beet cultivation area, production and the number of factories across regions.

\begin{tabular}{lccc}
\hline Bölge & $\begin{array}{c}\text { Şekerpancarı } \\
\text { Üretimi (Ton) }\end{array}$ & $\begin{array}{c}\text { Şekerpancarı } \\
\text { Ekim Alanı (Dekar) }\end{array}$ & Fabrika Sayısı \\
\hline Doğu Anadolu & 965214 & 217664,00 & 8 \\
\hline iç Anadolu & 11828061 & 1880171,00 & 12 \\
\hline Karadeniz & 1345582 & 257287,00 & 5 \\
\hline Marmara & 149111 & 24244,00 & 3 \\
\hline Ege & 1216477 & 221906,00 & 3 \\
\hline Akdeniz & 807942 & 131827,00 & 2 \\
\hline Güneydoğu Anadolu & 149613 & 19622,00 & 0 \\
\hline
\end{tabular}

3.2. TÜik (2015) Verilerine Göre, Yozgat Ilinin Şekerpancarı Üretimi Ne Kadardır? Yozgat İli, Türkiye Şekerpancarı Üretiminin Yüzde Kaçını Karşılamaktadır?

2015 TÜiK verilerine göre; Türkiye'nin toplam şekerpancarı üretimi 16.462.000 tondur. Bu üretimin \% 31.69'u Konya iline aittir. Konya ilinin toplam şekerpancarı üretimi 5.217.392 tondur. Konya ilinden sonra en fazla üretim1.640.493 ton ile Yozgat ilinde gerçekleşmektedir. Yozgat ilinin şekerpancarı üretimi, Türkiye üretiminin \% 9.97'sini karşılamaktadır. Bu iki ilimizi sırası ile Aksaray (\% 6.05), Eskişehir (\% 5.11), Kayseri (\% 5.10), Afyonkarahisar (\% 4.18), Karaman (\% 3.91), Tokat (\% 3.84) ve Sivas (\% 3.26) illeri takip etmektedir. (Şekil 4).

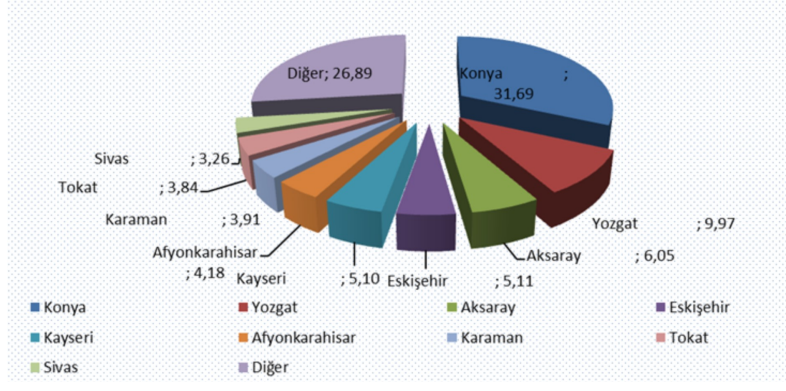

Şekil 4. İl bazında şekerpancarı üretiminin yüzdelik dağılımları (2015/TÜiK). Figure 4. Shares of the provinces in sugar beet production.

3.3. Yozgat ilinde Şekerpancarı Üretiminin Illçelere Göre Dağılımı Nasıldır? Bu Dağılımda Etkili Olan Coğrafi Esaslar Nelerdir?

2015 yılı Türkiye İstatistik Kurumunun verilerine göre; Yozgat Ilinin toplam şekerpancarı üretimi 1.640.493 tondur. Yozgat ilin 'deki şekerpancarı üretimini ilçelere göre değerlendirdiğimizde en fazla üretim 826147 ton ile Boğazlıyan ilçesine aittir. Bu ilçeyi sırası ile Sarıkaya (194354 ton), Merkez ilçe (145301 ton), Şefaatli (129610 ton) ve Yerköy (121834 ton) ilçeleri takip etmektedir. Yozgat ilinin kuzey, kuzeydoğu, doğu ve güneydoğu ilçelerinde şekerpancarı üretim değerleri oldukça düşüktür (Şekil 5). Yozgat ili genelinde en az üretim 198 kilo ile Çayıralan ilçesine aittir.

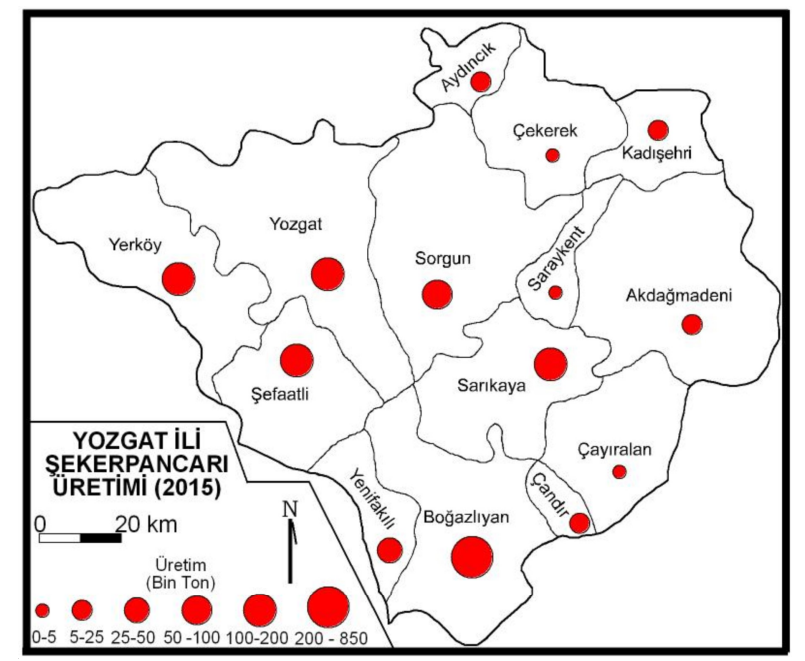

Şekil 5. Yozgat ili şekerpnacarı üretimi (2015/TüiK).

Figure 5. Sugar beet production of Yozgat province.

\subsubsection{Klimatolojik koşulların Yozgat ili şekerpancarı üretimine etkisi}

Şekerpancarında ekim tarihi, yabancı otlar, hastalıklar ve zararIılarla mücadele zamanı, vejetasyon periyodunun uzunluğu, hasat tarihi, kampanya başlangıç tarihi ve diğer işlemlerin ne zaman yapılacağını iklim koşulları belirlemektedir. (Rahimi ve Arslan, 2012).

"Şekerpancarı bitkisi, ılıman iklim bölgelerinde optimum ge- 
lişme gösterir. Sıcaklık şartlarının uygun olması durumunda, sulama yapmak koşuluyla kurak- yarıkurak bölgelerde rahatlıkla yetiştirilebilir. Bitkinin yetişme süresi 150-180 gün arasında değişir" (Şiray,1979, akt, Doğanay, 2007).

"Şeker pancarı sıcaklığı seven bir bitkidir. Şubat başı veya mart sonu ekilen tohumların çimlenebilmesi için ortalama sıcaklığın 7-8 ${ }^{\circ} \mathrm{C}$ 'den az olmaması, toprak sıcaklığının $2-3^{\circ} \mathrm{C}$ arasında olması gerekir. Büyüme devresinde (Mayıs- Haziran) bitkinin sıcaklık isteği artar. Gündüzleri sıcaklık $18-20{ }^{\circ} \mathrm{C}$ 'nin altına inmemelidir. Yetişme devresi boyunca sıcaklık ortalamaları 7-8 ${ }^{\circ} \mathrm{C}^{\prime}$ den az, $18-20{ }^{\circ} \mathrm{C}$ 'den fazla olmamalıdır. Yumru bağlama ve olgunlaşma dönemi olan Ağustos ve Eylül aylarında gece ve gündüz sıcaklık farklarının belirginleşmesi gerekir. Bu devre yumrunun seker biriktirme devresi olduğundan gündüzleri havanın ılık ve açık, geceleri serin geçmesi istenir (Şiray,1979, akt, Doğanay, 2007).

Yozgat ili uzun yıllar meteorolojik ölçümler; Merkez ilçe, Sorgun ve Boğazlıyan ilçelerinde bulunan meteoroloji istasyonlarının verileri ile sınırlıdır. Bu nedenle şekerpancarının klimatolojik yetişme koşulları üç ilçe merkezinin klimatolojik koşullarına göre yorumlanmıştır. Şekerpancarının yetişme koşullarını, Yozgat ili için değerlendirdiğimizde; bu değerler şekil 6 'da yer almaktadır. Şekerpancarı tohumların çimlenebilmesi için ortalama sıcaklığın 7-8 ${ }^{\circ} \mathrm{C}$ 'den az olmaması koşulunu Yozgat ili nisan ayından itibaren karşılamaktadır. (Şekil 6). Merkez'de nisan ayı sıcaklık ortalaması $8.5^{\circ} \mathrm{C}$, Sorgun ilçe merkezinde $9,7^{\circ} \mathrm{C}$ ve Boğazlıyan ilçe merkezinde $9,4^{\circ} \mathrm{C}^{\prime}$ dir. Bu ilçelerde nisan ayı pancar tohumlarının yetişebilmesi için ideal koşullar sunmaktadır.

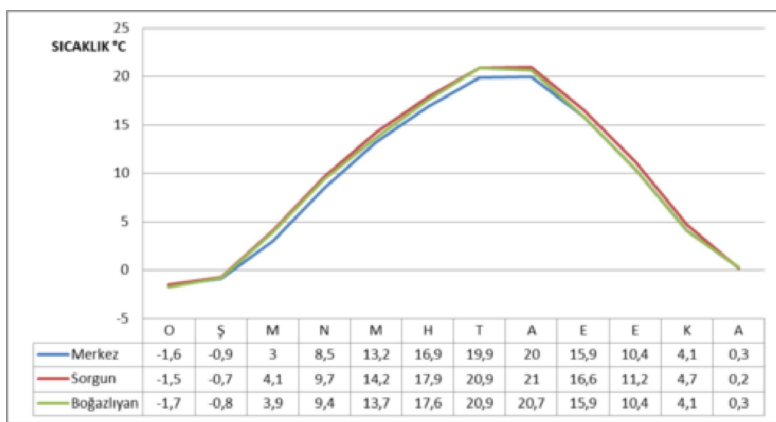

Şekil 6. Yıllık ortalama sıcaklıkların aylara dağılış grafiği (1980-2015). Figure 6. Monthly distribution of annual mean temperatures (1980-2015).

Büyüme devresinde (Mayıs - Haziran aylarında) bitkinin sıcaklık isteği artar. Yetişme devresi boyunca sıcaklık ortalamaları 7-8 ${ }^{\circ} \mathrm{C}$ 'den az, $18-20{ }^{\circ} \mathrm{C}$ 'den fazla olmamalıdır. Şekerpancarı bitkisinin mayıs - haziran aylarını kapsayan büyüme devresindeki sıcaklık istekleri Yozgat iline göre değerlendirildiğinde, Yozgat ili, bu bitkinin yetişmesi açısından ideal sıcaklık koşullarına sahiptir.

"Yetişme devresinde gün içerisindeki sıcaklıkların değişimi de pancarın gelişimini etkiler pancarın gelişmesinde gece ve gündüz sıcaklıkları önemlidir. Düşük gece sıcaklıkları topraktaki bitki besin maddelerinin ve nemin yeterli olması durumunda geçici olarak şeker yoğunluğunu artırır. En fazla şeker üretimi günlük sıcaklık farklarının $15^{\circ} \mathrm{C}$ olduğu zamanlarda ortaya çıkar" (Jonhson vd 1977, akt Avcı,1996). Şekerpancarı bitkisi, yumru bağlama ve olgunlaşma dönemlerinde gündüz ve gece sıcaklık farkları belirgin geçmesi gerekir. Yozgat ili genelinde karasal iklim koşulları hakim olduğundan gece ile gündüz sıcaklıkları oldukça belirgindir.

"Serin gecelerde bitkideki fizyolojik faaliyetler minimum düzeye indiğinden yumruda şeker tüketimi olmaz. Buna karşılık geceleri serin olmayan bölgelerde fizyolojik faaliyetler devam ettiğinden yumrudaki şekerin bir kısmı bu iş için harcanır" (Gediz, 1953; akt, Kadıoğlu,2009). "Sıcaklığın gece $15^{\circ} \mathrm{C}$, gündüz 20-23 ${ }^{\circ} \mathrm{C}$ olduğu zamanlarda pancarda şeker yoğunluğu maksimum düzeye çıkar. Bu değerlerinin gece $30^{\circ} \mathrm{C}$, gündüz $26^{\circ} \mathrm{C}$ ye çıkması durumunda şeker birikimi azalır" (Johnson ve diğerleri, 1977, akt Avcı: 1993). "Sıcaklık $30^{\circ} \mathrm{C}$ 'nin üzerine çıktığında gelişme durur ve bitki yumruda depo ettiği şekeri harcar" (Şiray,1990, akt Özçağlar, 1992).

“ilkbahar mevsimindeki donlar pancar tarlalarında hasar yapar. Tohum ekiminin yapıldığı dönemde toprak sıcaklığı -2 C'nin altına düşmemelidir. Şeker pancarında donma $-2.4{ }^{\circ} \mathrm{C}$ ile $-4.3{ }^{\circ} \mathrm{C}$ arasında baslar ve $-16^{\circ} \mathrm{C}$ 'de hücreler hayati faaliyetleri kaybeder" (Şiray,1990, akt, Özçağlar, 1992). Yozgat Merkez ilçe, Sorgun ve Boğazlıyan ilçelerinde $10 \mathrm{~cm}$ derinlikte toprak sıcaklıklarının $0{ }^{\circ} \mathrm{C}^{\prime}$ nin altına düşmemektedir. (Tablo 3). Toprak sıcaklığı, dona karşı pancar tohumlarına için uygun yetişme ortamı sunmaktadır.

Tablo 3. Ortalama $10 \mathrm{~cm}$ toprak sıcaklığı $\left({ }^{\circ} \mathrm{C}\right)$

Table 3. Mean temperature within 10 centimeters of depth.

\begin{tabular}{ccccccccccccc}
\hline ilcçe Merkezleri & $\mathbf{0}$ & $\mathbf{S}$ & $\mathbf{M}$ & $\mathbf{N}$ & $\mathbf{M}$ & $\mathbf{H}$ & $\mathbf{T}$ & $\mathbf{A}$ & $\mathbf{E}$ & $\mathbf{E}$ & $\mathbf{K}$ & $\mathbf{A}$ \\
\hline Merkez & 0.8 & 1.2 & 4.5 & 10.2 & 15.8 & 20.7 & 24.1 & 23.9 & 19.6 & 13.0 & 6.0 & 2.1 \\
\hline Sorgun & 0.7 & 1.6 & 5.9 & 11.2 & 16.8 & 21.5 & 24.8 & 25.1 & 20.8 & 14.0 & 6.3 & 1.6 \\
Boğazlıyan & 0.9 & 1.5 & 5.7 & 11.3 & 16.6 & 21.4 & 24.4 & 24.4 & 20.1 & 13.3 & 6.2 & 2.4 \\
\hline
\end{tabular}

"Şekerpancarı yetişme devresinden olgunlaşma devresine kadar yaklaşık 500 - 600 mm yağışa ihtiyaç duyar. Wahltmann'a göre yağışın aylara göre dağılımı büyük önem arz eder. Kış mevsiminde $240 \mathrm{~mm}$, nisan $40 \mathrm{~mm}$, mayıs $50 \mathrm{~mm}$, haziran $50 \mathrm{~mm}$, temmuz $80 \mathrm{~mm}$, ağustos $65 \mathrm{~mm}$, eylül $35 \mathrm{~mm}$ ve ekim $40 \mathrm{~mm}$ şeklinde olmalıdır" (Bilgin 1989, akt; Avcı,1996). "Bu yağış rejimine sahip olan yerlerde eğer diğer şartlar da uygunsa, pancar üretimi doğal olarak yapılabilir. Uymayan bölgelerde sulama zorunluluğu doğmaktadır"(Avcı,1996).

Yozgat ili çevresinde nisan ve mayıs aylarında yaşanan kırkikindi yağışları, bu aylarda sulamaya ihtiyaç duyulmamaktadır. Temmuz, ağustos ve eylül aylarındaki yağış değerleri her üç merkezde de oldukça düşüktür. Bu aylarda sulamaya ihtiyaç duyulmaktadır (Şekil 7).

\subsubsection{Jeomorfolojik yapının Yozgat ili şekerpancarı üretimine etkisi}

“Türkiye'de şeker pancarı tarım alanları, üretimde geniş çapta makinenin kullanılması ve sulamanın gerekliliği gibi nedenlerden dolayı daha çok az eğimli fakat iyi drene olmuş bölgelerde yoğunluk kazanır. Bu sahalar genellikle ovalar ve ova kenarındaki düzlüklerden oluşur. Ayrıca geniş vadi tabanları ve sulanabilenplato düzlükleri de pancar tarım alanları arasında yer alır" (Avcı, 1993-1996).

Yozgat ili jeomorfolojik ünite (ova, plato, dağlık, vadi) bakımından çeşitlilik gösterir. İl genelinin büyük bir kısmı yüksek ve akarsular tarafindan parçalanmış düzlüklerden oluşur (Şekil 8). il genelinde Bozok Platosu oldukça geniş yer kaplar. Merkez ilçe, 
Sorgun, Sarıkaya, Saraykent, Çekerek ilçelerinin büyük bir bölümü Bozok platosu içerisinde yer alır. Yerköy, Boğazlıyan ilçeleri alçak düzlükler inşa edilmiştir. Kadışehri'nin kuzeyinde Deveci Dağları oldukça geniş yer kaplar. Akdağmadeni, Çayıralan ve Çandır ilçeleri oldukça dağlık ve engeli bir yapı gösterir. Bu ilçe sınırları içerisinde Akdağlar oldukça geniş yer kaplar (Şekil 8). Yozgat ilinin kuzey, kuzeydoğu, doğu ve güneydoğu ilçelerinde (Aydıncık, Çekerek, Akdağmadeni, Çayıralan ve Çandır ) şekerpancarı üretim değerleri oldukça düşüktür. Bu ilçelerin şekerpancarı üretim değerlerinin düşük olmasında Deveci Dağlarının ve Akdağların bu sahada bulunması önemli bir etkendir (Şekil 8).

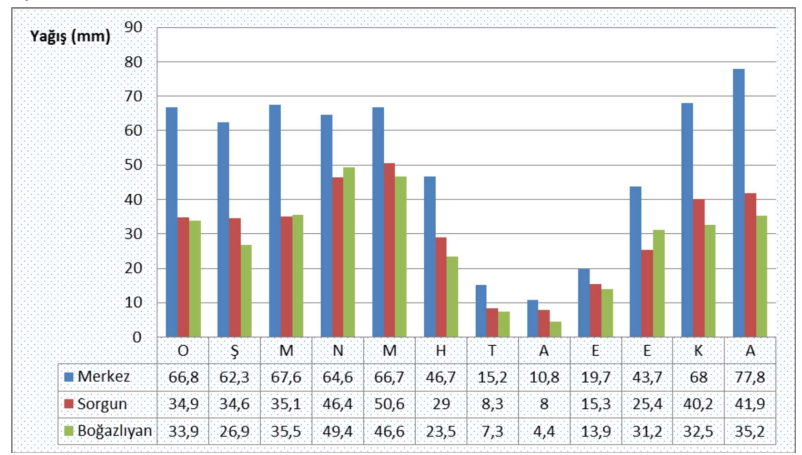

Şekil 7. Yıllık ortalama yağış miktarının aylara göre dağılış grafiği (1980-2015). Figure 7. Monthly distribution of annual precipitation 1980-2015).

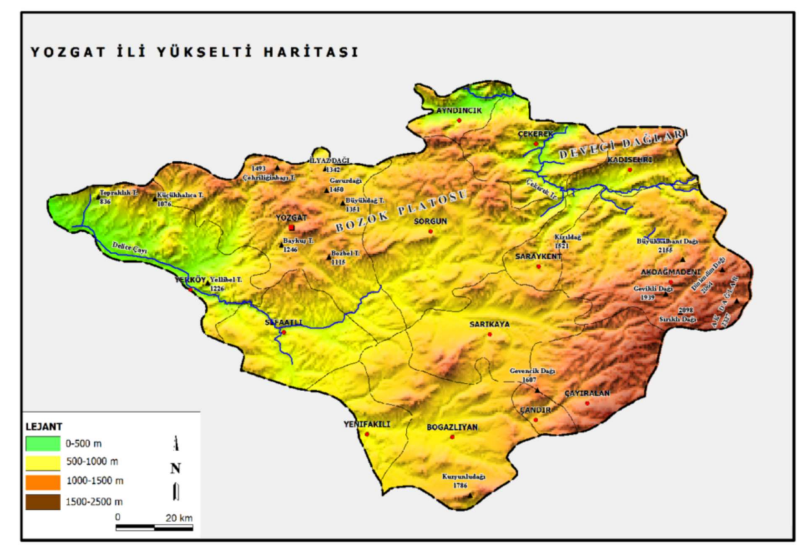

Şekil 8. Yıllık ortalama yağış miktarının aylara göre dağılış grafiği (1980-2015). Figure 8. Monthly distribution of annual precipitation 1980-2015).

Bu ilçeler oldukça dağlık ve engebeli bir yapıya sahiptir. Bu durum ilçelerde tarım alanlarının daralmasına neden olur (Tablo 4). Tarım alanlarının genişlediği, Boğazlıyan, Yerköy ilçelerinde ve Bozok Platosu (Merkez, Sorgun, Sarıkaya, Saraykent) ilçelerinde şekerpancarı üretimi fazladır.

Tablo 4 ve Tablo 5'ten anlaşılacağı üzere, topografik yapı, Yozgat ilindeki şekerpancarı ekim alanlarını ve ilçelere göre şekerpancarı üretim miktarını belirlemektedir. Nitekim tablo 5 'teki tarım alanı ile ekim alanı ve tarım alanı ile üretim arasında yüksek düzeyde pozitif anlamlı bir ilişkinin varlığı; Yozgat ili için şeker pancarının üretiminin coğrafi dağılımında en önemli doğal belirleyecinin topografya olduğunu göstermektedir.

Yozgat ili şekerpancarı üretimine etki eden tarım alanı ile ekim alanı, tarım alanı ile şekerpancarı üretimi, şekerpancarı üretimi ile ekim alanı ve verim ile üretim arasındaki ilişkiyi değerlendirmek amacıyla Sperman's Rho korelasyon analizi yapılmıştır. Bu analiz yöntemi verilerin normal dağılım göstermediği du- rumlarda kullanılmaktadır. Korelasyon katsayısı 0.70 ile 1.00 arasında ise ilişkinin yüksek düzeyde, 0.70 ile 0.30 arasında olması ilişkinin orta düzeyde 0.30 ile 0.00 arasında olması ise ilişkinin düşük düzeyde olduğunu göstermektedir (Büyüköztürk vd., 2009).

Tablo 4. Yozgat ili ilçe bazlı şekerpancarı üretimi ve tarım alanları.

Table 4. Sugar beet production and agricultural area across the counties of Yozgat.

\begin{tabular}{lcclll}
\hline ilçe Merkezi & $\begin{array}{c}\text { Üretim } \\
\text { (ton) }\end{array}$ & $\begin{array}{c}\text { Verim } \\
\text { (kg/da) }\end{array}$ & $\begin{array}{c}\text { Toplam Tarım } \\
\text { Alanı (Dekar) }\end{array}$ & $\begin{array}{c}\text { Toplam } \\
\text { Yüzölçüm } \\
\left(\mathbf{k m}^{2}\right)\end{array}$ & $\begin{array}{c}\text { Ekilen Alan } \\
\text { (Dekar) }\end{array}$ \\
\hline Boğazlıyan & 826147 & 6478 & 865948 & 1515 & 127522 \\
\hline Sarıkaya & 194354 & 5802 & 848613 & 1018 & 33500 \\
\hline Merkez & 145301 & 4835 & 860761 & 2024 & 30054 \\
Şefaatli & 129610 & 5147 & 720027 & 882 & 25050 \\
\hline Yerköy & 121834 & 5802 & 684860 & 1164 & 21000 \\
\hline Sorgun & 87024 & 5802 & 839520 & 1768 & 15000 \\
\hline Yenifakılı & 48867 & 5898 & 198849 & 390 & 8285 \\
\hline Çandır & 24173 & 4835 & 142257 & 205 & 5000 \\
\hline Akdağmadeni & 23932 & 4351 & 391137 & 1810 & 5500 \\
\hline Kadışehri & 21862 & 6708 & 133330 & 472 & 3230 \\
\hline Aydıncık & 12258 & 5138 & 126177 & 338 & 2305 \\
\hline Saraykent & 3483 & 4638 & 107503 & 319 & 751 \\
\hline Çekerek & 1450 & 4833 & 162180 & 790 & 300 \\
Çayıralan & 198 & 4829 & 202127 & 995 & 41 \\
\hline & & & & & \\
\hline
\end{tabular}

Tablo 5. Yozgat ili toplam tarım alanı, şekerpancarı ekim alanı, şekerpancarı üretimi ve verim arasındaki ilişkiyi gösteren Spearman's korelasyon katsayısı sonuçları.

Table 5. Spearman correlation coefficients showing the relationship between total agricultural area, area suitable for cultivation, production, fertility and the number of sugar factories in Yozgat.

\begin{tabular}{llllll}
\hline & & Tarım Alanı & Ekim Alanı & Üretim & Verim \\
\hline \multirow{2}{*}{ Tarım Alanı } & Spearman's Rho & 1 & & & \\
\cline { 2 - 3 } Ekim & $\mathrm{p}$ & - & & & \\
Alanı & Spearman's Rho & $0.837^{* *}$ & 1 & & \\
\multirow{2}{*}{ Üretim } & $\mathrm{p}$ & 0.000 & - & & \\
& Spearman's Rho & $0.820^{* *}$ & $0.996^{* *}$ & 1 & \\
\multirow{2}{*}{ Verim } & $\mathrm{p}$ & 0.000 & 0.000 & - & \\
& Spearman's Rho & 0.296 & 0.528 & $0.548^{*}$ & 1 \\
& $\mathrm{p}$ & 0.304 & 0.052 & 0.042 & - \\
\hline
\end{tabular}

** Korelasyon 0.01 düzeyinde anlamlıdır.

*Korelasyon 0.05 düzeyinde anlamlıdır.

Buna göre, Yozgat ilindeki tarım alanı ile ekim alanı arasında pozitif yönde, yüksek düzeyde ve anlamlı bir ilişki bulunmuştur $(r=0.84 ; p<0.01)$. Determinasyon katsayısı $\left(r^{2}=0.70\right)$ incelendiğinde; tarım alanındaki değişmelerin \%70'inin ekim alanından kaynaklandığı, aynı şekilde ekim alanındaki toplam değişmelerin \% 70'inin tarım alanından kaynaklandığı söylenebilir. Başka bir anlatımla tarım alanı arttıkça ekim alanı da anlamlı bir farklılık oluşturacak şekilde artmaktadır (Tablo 5).

Yozgat ilindeki tarım alanı ile üretim arasında pozitif yönde, yüksek düzeyde ve anlamlı bir ilişki bulunmuştur ( $r=0.82$; $p<0.01)$. Determinasyon katsayısı $\left(r^{2}=0.67\right)$ incelendiğinde; tarım alanındaki değişmelerin \% 67'sinin üretimden kaynaklandığı, aynı şekilde üretimdeki toplam değişmelerin \% 67'sinin tarım alanından kaynaklandığı söylenebilir.

Yozgat ilindeki şekerpancarı ekim alanı ile üretim arasında pozitif yönde, yüksek düzeyde ve anlamlı bir ilişki bulunmuştur $(r=0.99 ; p<0.01)$. Determinasyon katsayısı $\left(r^{2}=0.98\right)$ incelendiğinde; şekerpancarı ekim alanındaki değişmelerin \% 98'sinin üretimden kaynaklandığı, aynı şekilde üretimdeki toplam değişmelerin \% 98'sinin şekerpancarı ekim alanından kaynaklandığı söylenebilir.

Yozgat ilindeki üretim ile verim arasında pozitif yönde, orta dü- 
zeyde bir ilişki bulunmuştur $(r=0.54 ; p<0.05)$. Determinasyon katsayısı $\left(r^{2}=0.29\right)$ incelendiğinde; verimdeki değişmelerin \% 29'unun üretimden kaynaklandığı, aynı şekilde üretimdeki toplam değişmelerin \% 29'unun verimden kaynaklandığı söylenebilir.

\subsubsection{Jeolojik yapının Yozgat ili şekerpancarı üretimine etkisi}

Akdağlar, Karababa Dağı ve civarı, Akdağmadeni metamorfikleri olarak tanımlanan genellikle gnays, mermer, şist, kuvarsit ve amfibolitlerden oluşmaktadır (Şekil 9). Bu metamorfik kayalar bölgesel metamorfizmanın etkisi altında oluşmuş olup çok düşük dereceli metamorfizma koşullarından başlayıp, orta yüksek dereceli metamorfizma koşullarına kadar farklı şiddette oluşmuş kayaçlar bu sahada bulunmaktadır. Özellikle sarp topografyanın oluşmasına neden olan kayalar kuvarsit ve içeriğinde kuvars minerali bulunduran kayalar mineralin sertliğinden ve aşınmaya olan direncinden dolayı kolayca ufalanıp parçalanmaz ve topografyada çıkıntılar şeklinde yüzlekler sunar. Bu engebeli yüzlekler burada tarım alanlarının daralmasının da temel sebebidir. Tarım alanlarının daralmasına bağlı olarak ta buralarda şekerpancarı üretimi azalmıştır.

Ofiyolitik kayalar tek bir kayaç türü ile adlandırılmazlar. Bunlar birden fazla mafik - ultramafik ve bazik - ultrabazik kayaçlar topluluğudur. Bu kayaçlar tabandan tavana doğru jeolojik olarak bir kaya istifi şeklinde bulunurlar. Bunlar tabanda ultamafik tektonit, peridoditler, kümülat kayaları, izotrop ve tabakalı gabrolar, levha- dayk kompleksi ve epiofiyolitik sedimanter kayaçlardan oluşurlar. Şekil 9' dan anlaşılacağı üzere ofiyolitler tek bir kayacı değil bir kayaç topluluğunu ifade eder ve genellikle bu bölgeler eski okyanusal kalınt alanlarıdır. Bu kayaç topluluğu oldukça engebeli bir topografya sunar. Buna bağlı olarak Yozgat şehir merkezi ve çevresinde tarım alanları daralmıştır.

Boğazlıyan ve civarında ise hakim Üst Miyosen - Pliyosen, Pliyosen - Kuvaterner yaşlı iyi pekişmemiş oldukça genç karasal kırıntılı kayaçlardan oluşmaktadır. Bu kırıntılı kayaçlar iyi pekişmemiş ve çimentolanması oldukça zayıf kayaçlardır. Aşınmaya karşı dirençleri de çok zayıftır. Aşınmaya bağıı olarak Boğazlıyan ilçesinde geniş düzlükler oluşmuştur. Bu durum tarım alanlarının genişlemesine ve dolayıyla şekerpancarı üretiminin artmasına sebep olmuştur.

Yerköy ve civarında ise hakim Oligosen - Kuvaterner yaşlı iyi pekişmemiş karasal kırıntılı kayaçlardan oluşmaktadır. Bu kırıntılı kayaçlar aşınmaya karşı dirençleri oldukça zayıftır. Aşınmaya bağlı olarak Yerköy ilçesi ve çevresinde geniş düzlükler oluşmuştur. Bu durum tarım alanlarının genişlemesine ve dolayıyla şekerpancarı üretiminin artmasına sebep olmuştur.

\subsubsection{Illçelere göre, toprak gruplarının şekerpancarı üretimine etkisi}

"Şeker pancarı toprak özellikleri bakımından seçici değildir. Ancak derin, tınlı, humusça zengin, kum ve kil oranı düşük topraklarda ideal yetişme ortamı bulur. Asitli ve alkali toprakları sevmez. Taban suyu yüksek arazilerde verim düşer. Bu nedenle tarlaların hafif eğimli olması gerekir" (Doğanay, 2007). Çatal kök yapısına neden olduğu için taslı topraklar, fidelerin çıkısını geciktirdiği ve seker oranını düşürdüğü için asitli ve organik topraklar seker pancarı tarımına uygun değildir" (Yavuz, 1970, akt; Kadıoğlu,2009).

Şekil 3, şekil 5 ve şekil 10 analiz edildiğinde; şekerpancarı üretiminin alüvyon topraklar, kahverengi topraklar, kırmızımsı kahverengi topraklar, kolüvyal topraklar ve kestane renkli topraklar çevrelerinde yoğunlaşmaktadır. Kahverengi orman toprakları ve kireçsiz kahverengi orman topraklarının geniş alanlar kapladığı sahalarda şekerpancarı üretimi azalmaktadır (Şekil 10 ve Şekil 5)

\section{Sonuçlar ve Öneriler}

Yozgat ilinin büyük bir kısmındaki doğal şartlar, şeker pancarı tarımına büyük bir potansiyel sunmaktadır. Nitekim Türkiye İstatistik Kurumunun 2015 yılı verilerine göre, Yozgat ilinin şe

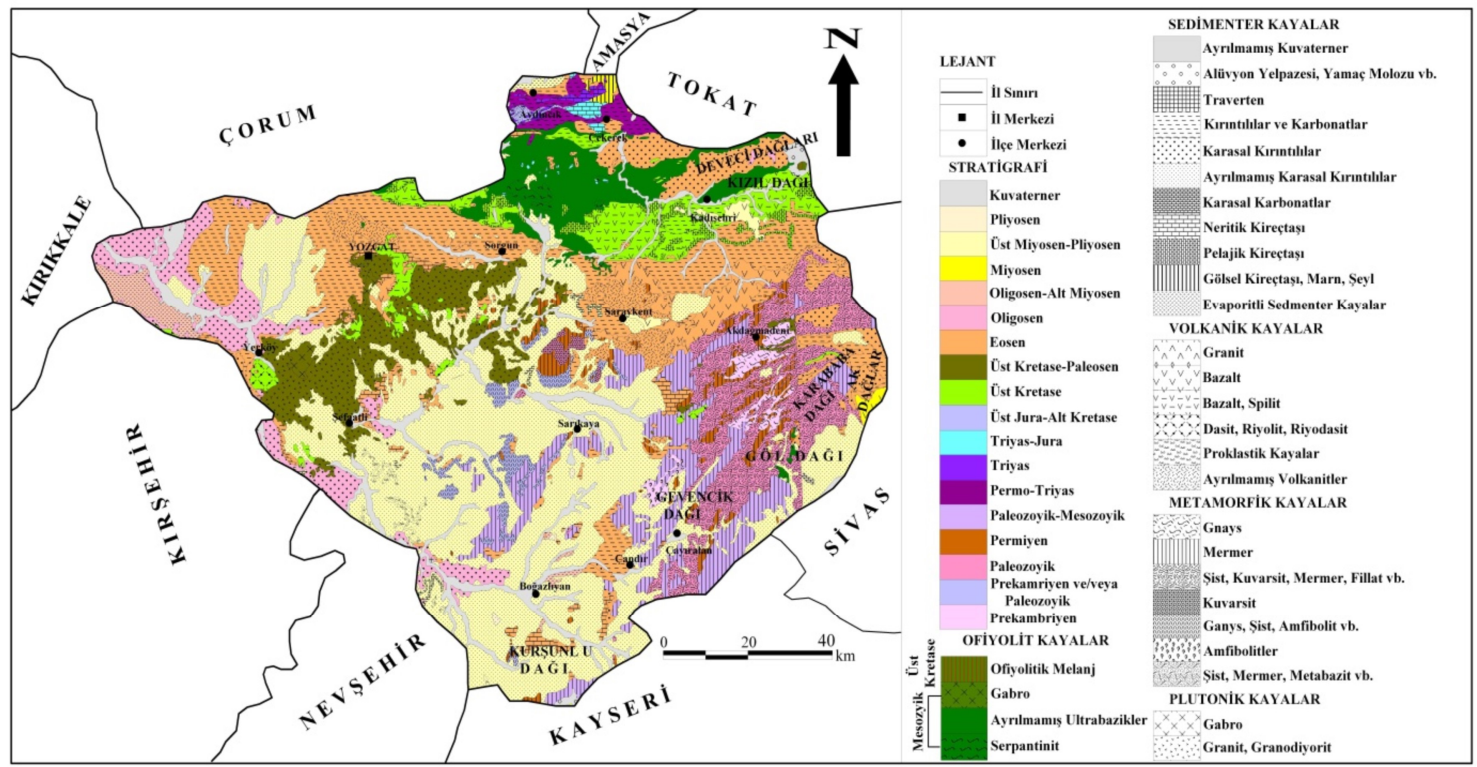

Şekil 9. Yozgat İli jeoloji haritası (MTA'nın 1/500.000 ölçekli haritalarından yararlanarak yeniden üretilmiştir.). Figure 9. Geological map of Yozgat provinces. 


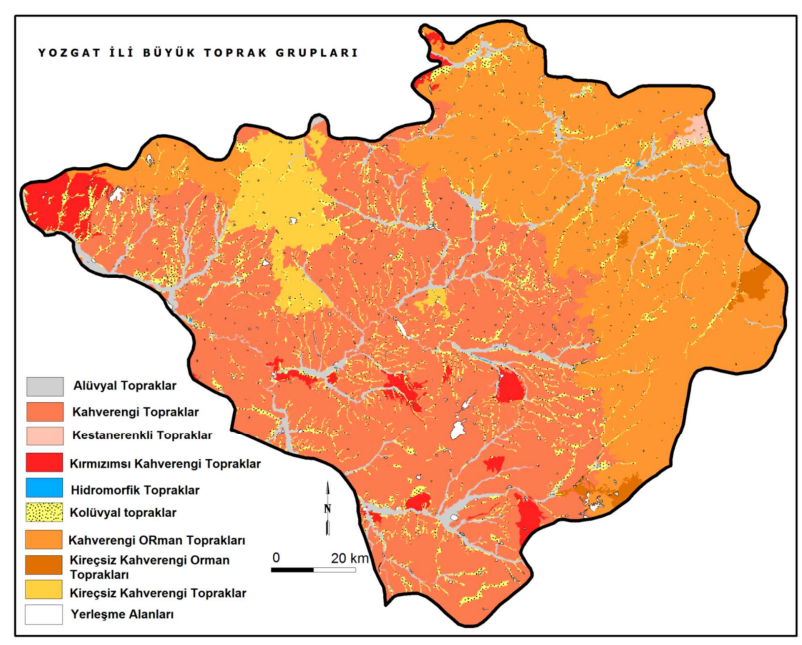

Şekil 10. Yozgat ili büyük toprak grupları haritası.

Figure 10. The map of largest soil groups of Yozgat Provinces.

kerpancarı üretimi 1.640 .493 tondur. Konya ilinden sonra en fazla üretim Yozgat ilinde gerçekleşmektedir. Yine Türkiye İstatistik Kurumunun 2015 verilerine göre, ülke bazında toplam şekerpancarı üretimi 16.462.000 milyon tondur. Yozgat ilinde üretilen şekerpancarı üretimi, Türkiye üretiminin \% 9.97'sini karşılamaktadır.

II bazında şekerpancarı üretimi daha çok jeolojik ve topografik faktörlere bağlı olarak şekillenmiştir. Şekerpancarı üretimi Boğazlıyan, Sarıkaya, Merkez ilçe, Şefaatli ve Yerköy ilçelerinde yoğunlaşmaktadır. En az üretim Çandır, Çekerek, Saraykent, Akdağmadeni ilçelerindedir.

Yozgat ili genelinde karasal iklim koşulları hakim olduğundan gece ile gündüz sıcaklıkları oldukça belirgindir. Gündüz sıcaklıkların $26^{\circ} \mathrm{C}^{\prime}$ nin üzerinde çıkmaması, gece ve gündüz sıcaklık farklarının belirgin olması, ortalama 550-600 mm civarında il genelinde yağışların gerçekleşmesi şekerpancarı üretiminin il genelinde canlandırmıştır. Bu açıdan değerlendirildiğinde klimatik koşullar şekerpancarı tarımına uygun koşullar sunmaktadır.

Yozgat ilindeki tarım alanı ile şekerpancarı ekim alanı arasında pozitif yönde, yüksek düzeyde anlamlı bir ilişki, il tarım alanı ile şekerpancarı üretimi arasında pozitif yönde, yüksek düzeyde anlamlı bir ilişki ve şekerpancarı ekim alanı ile şekerpancarı üretimi arasında pozitif yönde, yüksek düzeyde ve anlamlı bir ilişki bulunmuştur. Yozgat ilinde şekerpancarı üretim ile verim arasında pozitif yönde, orta düzeyde bir ilişki bulunmuştur.

Bu araştırmanın önemli sonuçlarından bir tanesi, Yozgat ilinde şekerpancarı üretimi ile verim arasında pozitif yönde orta düzeyde bir ilişki bulunmuştur. Bu ilişkinin yüksek düzeye getirilebilmesi için Yozgat il koşullarında şeker pancarı çeşitlerinin verim ve kalite özelliklerinin belirlenmesine yönelik çalışmalara intiyaç duyulmaktadır. Bu çalışmalar tamamlandığı vakit, Yozgat ili için verim ve kalitesi yüksek olan çeşit ve çeşitler üretilmeli ve bu amaca uygun ıslah çalışmaları yapılmalıdır.

Şekerpancarı bitkisi, şeker üretiminin yanı sıra melas, küspe, yaprak ve baş artıkları gibi yan ürünlerinden hayvan yemi, melastan alkol ve ispirto elde edilmesine katkı sağlayan bir bitkidir. Yozgat ili, bu bitkinin üretiminde, Türkiye'de önemli bir potansiyele sahip olmasına rağmen, bu bitkiye dayalı hayvan yem sa- nayinin ve alkol ve ispirto üretim atölyelerinin kurulmamaları düşündürücüdür. Bu sektörlerle yönelik fizibilite çalışmaları hızlandırılmalı ve şekerpancarı üretimi ile koordineli işbirliğine gidilmesi il genelinde yaşanan büyük miktarlardaki göçleri yavaşlatacağı düşünülmektedir.

\section{Kaynakça}

Avcı, S. (1993-1996). Türkiye'de Şeker Pancarı Ziraatının Coğrafi Esasları, İstanbul Üniversitesi Ed. Fak. Coğrafya Bölümü Coğrafya Dergisi sayı :4, s: 267- 270.

Büyüköztürk Ş., Çakmak K.E, Akgül E.Ö., Karadeniz Ş ve Demirel F. (2009). Bilimsel Araştrma Yöntemleri, Ankara: Pegem Akademi.

Çatal, M.I. ve Akındemir, F.(2013).Konya Koşullarında Bazı Şeker Pancarı Çeşitlerinin Verim ve Kalite Özelliklerinin Belirlenmesi, Selçuk Tar Gıda Bil Der, 27(2):112-120.

Çelikel, B. (1989). Şeker Pancarı Çeşitlerinde Verim ve Verim Unsurları Üzerinde Bir Araştırma. Yüksek Lisans Tezi. Trakya Üniversitesi (Basılmamış), Tekirdağ.

Doğanay, H. (2007). Ziraat Coğrafyası, Ekonomik Coğrafya 3, Aktif Yayınevi, Ankara.

Er, C. (2012). Şeker ve Şeker Pancarının Dünü, Bugünü ve Geleceği, 1. Uluslararası Anadolu Şeker Pancarı Sempozyumu, s:1-12, Kayseri.

Gediz, A. (1953). 1953, 1952 Senesi Almanya, Hollanda, Fransa, ispanya ve İsviçre'de Şeker Pancarı Ziraatının Son Durumu, T.S.F.A.S. Neşriyatı No: 24, Doğan Kardeş Yayınları A.S. Basımevi, Ankara.

Johnson R.T, Alexander, J.T., Rush, G.E and Hawkes, G.R.(1977).Şekerpancarı Üretimindeki Gelişmeler: Prensipler ve Uygulamalar, Türkiye Şeker Fabrikaları A.Ş. Yayını, Ankara.

Kadıoğlu, Y.(2009).Çivril'de Şekerpancarı Tarımının Coğrafi Özellikleri, Doğu Coğrafya Dergisi, Sayı:22, s:107-124.

Karaibiş D. ve Emeklier, H.Y. (2012). Pancar Şekeri Mi? Mısır Şekeri Mi?, 1. Uluslararası Anadolu Şeker Pancarı Sempozyumu, s:85-90, Kayseri.

Karasar, N. (1999). Bilimsel Araştırma Yöntemi, Ankara: Nobel Yayınları.

Kaya, S., Meral, R. ve Demir, A.D. (2012). Erzurum Ovası Koşullarında Şeker Pancarının Sulama Programının Belirlenmesi, Uluslararası Anadolu Şeker Pancarı Sempozyumu, s:209 -214, Kayseri.

Konyalı, S ve Şatana, A. (2012). Şeker Pancarı Tarımının ve Şeker Sektörünün SWOT Analizi ile Değerlendirilmesi: Trakya Bölgesi Örneği, 1. Uluslararası Anadolu Şeker Pancarı Sempozyumu, s:64-70, Kayseri.

Rahimi, A. ve Arslan, N. (2012). Farklı Rakımlarda Yetişen Şekerpancarlarının Kalite Yönünden Karşılaştıııması, Uluslararası Anadolu Şeker Pancarı Sempozyumu, s:136 -142, Kayseri.

Söğüt, T., Arıoğlu, H.H. (1999). Diyarbakır koşullarında bazı şeker pancarı (Beta vulgaris L.) çeşitlerinin önemli tarımsal ve kalite özelliklerinin belirlenmesi. Türkiye 3. Tarla Bitkileri Kongresi. Adana. 15-18 Kasım 2: 82-87.

Şiray, A.(1990).Şeker pancarı Tarımı, Pankobirlik Yayınları. No: 2, Ankara.

Okut, N. ve Yıldırım, B.(2004). Van Koşullarında Şeker Pancarı Çeşit ve Ekim Zamanının Verim, Verim Unsurları ve Kalite Üzerine Etkisi, Yüzüncü Yıl Üniversitesi, Ziraat Fakültesi, Tarım Bilimleri Dergisi (J. Agric. Sci.), 14(2): 149-158.

Özçağlar, A. (1992). Türkiye'de Seker Pancarı Ekim Alanlarının Coğrafi Dağılışı, Türkiye Coğrafyası Uygulama ve Araştırma Merkezi Dergisi, sayı :1, s: 18- 30.

Yardımcı, N., Çulal Kılıç H. ve Ürgen G. (2012). Eskişehir îli Şeker Pancarı Üretim Alanlarında Görülen Virüs Hastalıklarının DAS-ELiSA Yöntemiyle Belirlenmesi, Süleyman Demirel Üniversitesi Ziraat Fakültesi Dergisi 7(1):42-50.

Yavuz, M.L. (1970). Orta Anadolu ve Marmara İklim ve Toprak Sartlarında Su ve Azotun Şeker Pancarının Verim ve Kalitesine Etkileri Üzerine Bir Araştırma, T.F.S.F. Yayını Ankara. 